\section{Commentary: Ionic heterogeneity in vessel grafts}

\author{
Jun Feng, MD, PhD, and Frank W. Sellke, MD
}

Although both arteries and veins function as conduits, they differ in fundamental ways. ${ }^{1}$ In the systemic circulation, arteries carry well-oxygenated blood, whereas veins contain deoxygenated blood. Structurally, arteries have thick walls, pulsate, and lack valves, whereas veins have thin walls, do not pulsate, and have valves to maintain blood flow in one direction. Finally, endothelial cells (ECs) produce more nitric oxide (NO) and endothelial junctions in tighter arteries than those in veins. ${ }^{1}$

It is well documented that vascular smooth muscle cells (VSMCs) and ECs are uniquely adapted to the needs of underlying tissues. As such, the structure and function of VSMCs and ECs display remarkable heterogeneity. ${ }^{1}$ For instance, although both the internal mammary artery (IMA) and saphenous vein (SV) have been routinely used in coronary artery graft surgery, the IMA graft has been generally recognized to be superior in long-term patency and clinical outcomes. $^{2-4}$ When veins are grafted into the arterial circulation, venous arterialization is initially adaptive but can ultimately contribute to graft remodeling/failure.

In this observational study, Sun and colleagues ${ }^{5}$ observed that IMA and SV differ in the subtype abundance of calcium-activated potassium $\left(\mathrm{K}_{\mathrm{Ca}}\right)$ channels in VSMCs and ECs. Furthermore, large-conductance $\mathrm{K}_{\mathrm{Ca}}\left(\mathrm{BK}_{\mathrm{Ca}}\right)$ channels were found to play a critical role in IMA relaxation. These observations extend previous studies ${ }^{6,7}$ by comparing the protein expression and vessel reactivity of $\mathrm{BK}_{\mathrm{Ca}}$, intermediate-conductance $\mathrm{K}_{\mathrm{Ca}}\left(\mathrm{IK}_{\mathrm{Ca}}\right)$ channels as well as the small-conductance $\mathrm{K}_{\mathrm{Ca}}\left(\mathrm{SK}_{\mathrm{Ca}}\right)$ channels between IMA and SV. $\mathrm{K}_{\mathrm{Ca}}$ channels are the key regulators of vascular tone, and their heterogeneity may contribute to the diverse responses of vessel grafts.

There are a number of limitations in this pilot study, however. First, the authors did not record $\mathrm{K}^{+}$currents in the

\footnotetext{
From the Division of Cardiothoracic Surgery, Cardiovascular Research Center, Rhode Island Hospital, Providence, RI

Disclosures: Authors have nothing to disclose with regard to commercial support.

Received for publication Nov 19, 2019; revisions received Nov 19, 2019; accepted for publication Nov 20, 2019; available ahead of print Nov 27, 2019.

Address for reprints: Jun Feng, MD, PhD, 1 Hoppin St, Coro West Room 5.229, Cardiothoracic Surgery Research Laboratory, Rhode Island Hospital, Providence, RI 02903 (E-mail: jfeng@lifespan.org).

J Thorac Cardiovasc Surg 2021;161:e411-2

$0022-5223 / \$ 36.00$

Copyright (c) 2019 by The American Association for Thoracic Surgery

https://doi.org/10.1016/j.jtcvs.2019.11.036
}

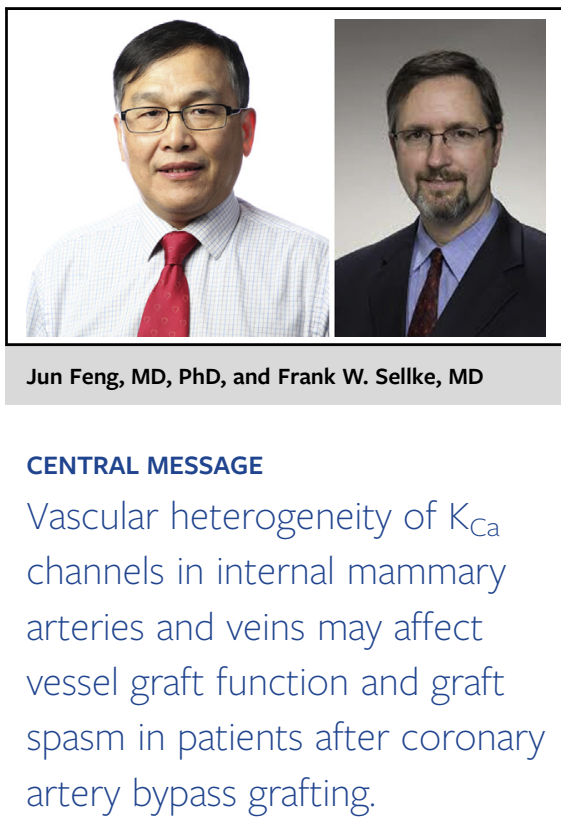

VSMCs and ECs of IMA and SV to support their findings of protein expression of $\mathrm{K}_{\mathrm{Ca}}$ channels and vessel relaxation response to $\mathrm{K}_{\mathrm{Ca}}$ channel activators. Second, the authors did not address the discrepancies in $\mathrm{K}_{\mathrm{Ca}}$ channel expression and vascular reactivity compared with previous studies. ${ }^{6,7}$ Third, the authors did not provide detailed information regarding patient characteristics in the enrolled 50 cases. The impact of age and sex differences on protein expression and vessel reactivity of $\mathrm{K}_{\mathrm{Ca}}$ channels warrant further analysis. The potential effects of atherosclerosis, metabolic syndrome, hypercholesterolemia, diabetes, hypertension, obesity, and related medications should be analyzed and discussed, because these factors may impact the protein expression, current density, and vessel reactivity of $\mathrm{K}_{\mathrm{Ca}}$ channels. Indeed, the molecular, cellular, and functional heterogeneity of $\mathrm{K}_{\mathrm{Ca}}$ channels is even more prominent in diseased vasculature. The authors provide very limited but nonetheless insightful information on the vascular heterogeneity of $\mathrm{K}_{\mathrm{Ca}}$ channels between IMA and SV.

The molecular and cellular heterogeneity and plasticity of VSMCs and ECs complicate investigations in the context of healthy and diseased vasculature. Vascular heterogeneity of ion channels is an underappreciated phenomenon that merits further exploration in vessel grafts. A better understanding of the ionic heterogeneity in vessel grafts may allow for therapeutic targeting of $\mathrm{K}_{\mathrm{Ca}}$ channels to achieve antispasmodic effects, which can also be attributed to $\mathrm{K}_{\mathrm{Ca}}$ channels. 


\section{References}

1. Aird WC. Phenotypic heterogeneity of the endothelium: I. Structure, function, and mechanisms. Circ Res. 2007;100:158-73.

2. Shah PJ, Gordon I, Fuller J, Seevanayagam S, Rosalion A, Tatoulis J, et al. Factors affecting saphenous vein graft patency: clinical and angiographic study in 1402 symptomatic patients operated on between 1977 and 1999. J Thorac Cardiovasc Surg. 2003;126:1972-7.

3. He GW. Arterial grafts for coronary surgery: vasospasm and patency rate. J Thorac Cardiovasc Surg. 2001;121:431-3.

4. Schachner T. Pharmacological inhibition of vein graft neointimal hyperplasia. $J$ Thorac Cardiovasc Surg. 2006;131:1065-72.
5. Sun WT, Hou HT, Chen HX, Xue HM, Wang J, He GW, et al. Calcium-activated potassium channel family in coronary artery bypass grafts. $J$ Thorac Cardiovasc Surg. 2021;161:e399-409.

6. Archer SL, Gragasin FS, Wu X, Wang S, McMurtry S, Kim DH, et al. Endothelium-derived hyperpolarizing factor in human internal mammary artery is 11,12-epoxyeicosatrienoic acid and causes relaxation by activating smooth muscle $\mathrm{BK}(\mathrm{Ca})$ channels. Circulation. 2003;107: 769-76.

7. Bi D, Toyama K, Lemaitre V, Takai J, Fan F, Jenkins DP, et al. The intermediate conductance calcium activated potassium channel $\mathrm{K}_{\mathrm{Ca}} 3.1$ regulates vascular smooth muscle cell proliferation via controlling calcium-dependent signaling. $J$ Biol Chem. 2013;288:15843-53
See Article page e399.

\section{Commentary: Ions from eons: A hidden therapeutic potential of the resting potential?}

\author{
Phillip S. Naimo, MD, ${ }^{a, b, c}$ and \\ Igor E. Konstantinov, MD, PhD, FRACS ${ }^{\mathrm{a}, \mathrm{b}, \mathrm{c}, \mathrm{d}}$
}

Calcium-activated potassium channels, particularly, large conductance potassium channels $\left(\mathrm{BK}_{\mathrm{Ca}}\right)$, have been identified in virtually every type of smooth muscle. In blood vessels, they are involved in vascular tone regulation. In the uterus, $\mathrm{BK}_{\mathrm{Ca}}$ channels participate in the control of myometrial cell membrane potentials. ${ }^{1}$ In the airway, $\mathrm{BK}_{\mathrm{Ca}}$ channels regulate the tone and contractility of bronchioles. ${ }^{1}$ In gastrointestinal tract, $\mathrm{BK}_{\mathrm{Ca}}$ channels are involved in the regulation of colonic motility. ${ }^{1}$

Potassium is one of the most common ions in living cells, and potassium channels are ubiquitous to all domains of life. The ion-channel superfamilies are thought to be as ancient as the last common ancestor of all organisms on earth. ${ }^{2}$ Because of their wide distribution, potassium channels are thought to be one of the first ion

From the ${ }^{\mathrm{a} D e p a r t m e n t}$ of Cardiac Surgery, Royal Children's Hospital, ${ }^{\mathrm{b}}$ Department of Paediatrics, University of Melbourne, 'Heart Research Group, Murdoch Children's Research Institute, and 'Melbourne Children's Centre for Cardiovascular Genomics and Regenerative Medicine, Melbourne, Australia.

Disclosures: Authors have nothing to disclose with regard to commercial support.

Received for publication Nov 26, 2019; revisions received Nov 26, 2019; accepted for publication Dec 3, 2019; available ahead of print Dec 23, 2019.

Address for reprints: Igor E. Konstantinov, MD, PhD, FRACS, Royal Children's Hospital, Flemington Rd, Parkville, VIC 3052, Australia (E-mail: igor.konstantinov@ rch.org.au).

J Thorac Cardiovasc Surg 2021;161:e412-3

0022-5223/ $\$ 36.00$

Crown Copyright (C) 2019 Published by Elsevier Inc. on behalf of The American Association for Thoracic Surgery

https://doi.org/10.1016/j.jtcvs.2019.12.020
Check for updates

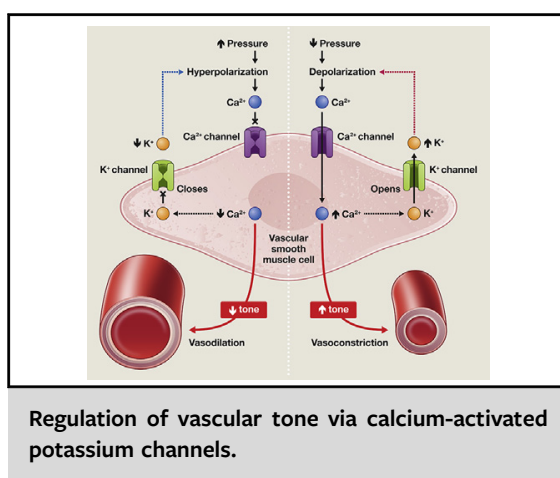

CENTRAL MESSAGE

Large calcium-activated potas-

sium channels may play an

important role in vasodilation of

the internal thoracic artery.

channels to have evolved. The evolution of potassium channels has been traced back to the prokaryotic world. ${ }^{3}$ Furthermore, small potassium channels have been found in viruses, which are some of the simplest potassium channels, and this has been suggested to predate the more complex channels seen in early bacteria. There have been both major (gene fusion and gene duplications) and minor (single-base mutations and deletions) genetic events that have led to the fascinating diversity of potassium channels that we see today. ${ }^{3}$ Amazingly, the general molecular characteristics of the $\mathrm{BK}_{\mathrm{Ca}}$ channels are evolutionarily conserved from worms to mammals. ${ }^{1,4}$ A single mammalian gene may generate many variants of $\mathrm{BK}_{\mathrm{Ca}}$ channels that may explain the variation in calcium sensitivity in blood vessels.

$\mathrm{BK}_{\mathrm{Ca}}$ channels appear to play a crucial role in arterial smooth muscle tone by providing a negative feedback 